\title{
Influence of dates on sowing and weather parameters incidence and development of Alternaria leaf spot of sesame
}

\author{
C.S. CHOUDHARY*1, ANJANA ARUN ${ }^{1}$ AND S.M. PRASAD ${ }^{2}$ \\ ${ }^{1}$ Regional Research Station, Agwanpur, SAHARSA (BIHAR) INDIA \\ ${ }^{2}$ Department of Plant Pathology, Birsa Agricultural University, RANCHI (JHARKHAND) INDIA
}

\section{ARITCLE INFO \\ Received : 27.08 .2014 \\ Revised : 27.01.2015 \\ Accepted : 14.02 .2015}

KEY WORDS :

Sesame, Dates of sowing, Weather parameters, Alternaria leaf spot disease

*Corresponding author:

Email: csrau07@gmail.com

\begin{abstract}
The crop sown on June 5, recorded lowest percentage Alternaria leaf spot disease intensity (PDI) of 19.25 and 26.00 per cent during Kharif, 2002-03 and 2003-04 crop seasons, respectively. A relatively higher PDI was recorded with the advancement of dates of sowing. The late sowing (August) crop favoured quick disease development and recorded highest (60.50 and $70.50 \%)$ disease intensity. The mean temperature 21.94 to $29.14^{\circ} \mathrm{C}$; mean relative humidity 74.35 to 90.63 per cent, mean rainfall of 7.81 to $12.33 \mathrm{~mm}$ and 38 to 40 rainy days during the seasons favoured disease development. Highest seed yield of $380.0 \mathrm{~kg} / \mathrm{ha}$ and $364.0 \mathrm{~kg} / \mathrm{ha}$ were recorded when crop was sown timely on $25^{\text {th }}$ June during both the years, respectively. Multiple regression equation between disease index and weather variables exhibited strong relationship among the different components of epiphytotics during both the years of study and indicated that the combined effect of different weather variables favoured the disease development causing upto 99 per cent variation in the disease index.
\end{abstract}

How to view point the article : Choudhary, C.S., Arun, Anjana and Prasad, S.M. (2015). Influence of dates on sowing and weather parameters incidence and development of Alternaria leaf spot of sesame. Internat. J. Plant Protec., 8(1) : 73-76. 